\title{
SPOREN VAN TWEEHONDERD JAAR HERRNHUTTERZENDING
}

\author{
DOOR
}

H. SCHÜTZ

Het zou de moeite loonen, eens uitvoerig na te gaan, in hoever de Herrnhutterzending haar stempel op de Surinaamsche samenleving gezet heeft. Men mag toch aannemen, dat een voortdurende beïnvloeding tweehonderd jaren lang op een volk, dat juist in dien tijd zich ontwikkeld heeft, van blijvende beteekenis is geweest. Hetgeen hier volgt maakt geenzins aanspraak op volledigheid; het wil slechts bij gelegenheid van het jubileum dezer zending wijzen op een en ander, waarbij die invloed duidelijk aan te toonen is. Misschien zal een ander zich ertoe aangetrokken gevoelen, om dieper te graven en daardoor meer aan het licht te brengen.

Wat den vreemdeling, die voor het eerst een Herrnhuttergemeente bezoekt, het meest opvalt, is de zeer bijzondere bouwtrant. In Zeist zijn de meeste huizen barok, en is de kerk als het middenpunt van den bouw genomen. Dit is een voorbeeld. Overal schikt men zich naar den aangenomen bouwtrant; ook de particulieren doen dat. Liefst bouwt men de kerk in tusschen de pastorie en de andere dienstgebouwen (Gnadau bij Maagdenburg bijvoorbeeld). In de Broedergemeente heet de kerk „Gemeinsaal”. Wat het uiterlijk betreft onderscheidt zij zich niet van de andere gebouwen, afgezien dan van de grootte. De „Kleine Saal”, die bij avonddiensten in de week gebruikt wordt, is vaak slechts een zaal in een dienstgebouw of „Chorhaus” (Zeist).

Van deze zeer bijzondere bouworde is in Suriname niet veel te merken. Onze kerken zijn stijlloos, zooals de groote stadskerk, of naar bouwdoozen-voorbeeld gebouwd (Noorderkerk, Saron). Het gebroken dak met een dakruiter, dat in de Broedergemeente gebruikelijk is, vindt men nergens in Suriname. Bij de verbouwing van de „stadszending” heeft men getracht dezen Broedergemeentestijl te benaderen door een luchtkoker als dakruiter uit te bouwen. 
Het behoeft ook niet te verwonderen, dat deze bouwtrant geen ingang gevonden heeft in Suriname. Niet zoozeer omdat men hier te maken had met bouw in de tropen, want geen der oude gebouwen in Suriname is een tropenhuis, het zijn alle houten patriciërshuizen of stijllooze gebouwen. Ook is de zending niet met bouwen begonnen; zij richtte zich in in tweedehandsche huizen, die vergroot werden door aan de werkplaats een vleugel te bouwen, die als „Sälchen” kon dienst doen. Dit wat de stad betreft en de plantages; in Indianen- en Boschnegerdorpen kon men geen barokhuizen bouwen van pinabladen. Door de nood is men echter toch wel tot een eigen kerkstijl gekomen, nl. tot de school- en woonkerk. Dit model vindt men nog in Albina, waar de leeraarswoning boven de kerk is. Het oudste voorbeeld is de groote stadskerk, die bestaat uit een groot hoog schip met een omloopend koor en als derde verdieping daarboven de woningen der leeraren. Van deze woningen zagen de ramen deels op straat, deels in het schip van de kerk uit. Het spreekt vanzelf, dat voor gezinnen met kleine kinderen deze woningen niet ideaal waren. Tegenwoordig doen deze vroegere woonkamers nog slechts als vergader- en vereenigingslokalen dienst.

Op de begraafplaatsen heeft de Herrnhutterstijl wel eenigen invloed gehad. Een kerkhof heet in de Broedergemeente niet „Friedhof”, zooals gewoonlijk in kerkelijke kringen in Duitschland, maar „Gottesacker”, Gods akker, „ein Garten, in den das Korn der Verwesung eingesenkt wird. Er ist in Beete eingeteilt, und in diesen Beeten liegen die entschlafenen Glieder der Gemeine nach Chören geordnet bei einander...." (Bettermann, Theologie und Sprache bei Zinzendorf). In Suriname heeft men getracht, dit eigen karakter vooral tot uiting te doen komen op de gedeelten, die voor de ontslapen zendelingen en hun kinderen bestemd zijn. Daar vindt men dezelfde platte steen als in de Duitsche gemeenten. Alleen ligt deze hier met het oog op het welig groeiende onkruid en de zware slagregens op een laag metselwerk. Daardoor heerscht op de Herrnhutter begraafplaats een zekere eenvormigheid, die men elders niet aantreft (bijv. in de Oranjetuin).

De oude zendelingen moesten en wilden, voor zoover dat mogelijk was, zelf in hun onderhoud voorzien. Zij trachtten dit te doen door landbouw. Hierdoor hoopten zij tegelijkertijd de jonge gemeenten bijeen te houden en aan geregeld werk te gewennen. Bij de Indianen in Berbice scheen dit aanvankelijk te gelukken. Men moet daarover niet te min denken. Het is toch heel wat, van 
zwervende Indianen een gevestigde landbouwende gemeenschap te maken. Het goede voorbeeld van de zendelingen had invloed. De zeer begaafde Schuhmann, talenkenner en leeraar aan het seminarium, werkte zelf in zijn "Kassabi Grund”.

Toch heeft dit pogen gefaald; ten deele door de overlast der militairen, die geregeld deze grondjes kwamen leegplunderen; het is de vraag, of ook op den duur niet het zwerversbloed der Indianen hun te machtig zou zijn geworden,.... en hun gemakzucht ook.

Ook de „Vrijnegers” heeft men niet tot geregelde landbouwers kunnen opleiden. Hoe vaak is de eerste post verplaatst moeten worden, omdat de roofbouw der Boschnegers de gronden uitmergelde, en zij niet tot stelselmatigen landbouw te bewegen waren. De proef, door de zendelingen ondernomen, om in het Boschland een koffieplantage aan te leggen, is als een mislukking te beschouwen.

Evenmin is men erin geslaagd, den gemiddelden Creool na de slavenbevrijding tot landbouwer op te voeden.

De praktijk was, dat de meeste zendingsposten wel een stuk grond bezaten, met cacao, yams en andere cultuurgewassen beplant, maar de opbrengst hiervan was zeer gering, en vele de moeilijkheden en groot het verdriet, dat dit bezit met zich bracht.

Misschien heeft de plantage Beekhuizen, die veel later in het bezit der zending kwam, eenigen invloed op de bevolking gehad. Deze plantage is zelfs een soort modelboerderij geworden, waar men dure proeven met rasvee en landbouwmachines aangedurfd heeft. Ik meen, dat enkele middenstands-boeren hier hun opleiding hebben gehad. Later heeft men ook getracht, daar jongens voor den landbouw op te leiden met de bedoeling, hen na volbrachten leertijd te helpen aan het bezit van een stuk eigen land en van een eigen huisje, maar ook dit is minder geslaagd.

Bij dit alles moet niet vergeten worden, dat de zendelingen over het algemeen geen landbouwdeskundigen waren, en dat zij moesten strijden tegen den afkeer van het landbouwbedrijf bij de bevolking.

Meer voorspoed heeft de zending gehad bij de opleiding van ambachtslieden. Reeds in hun eerste brieven uit Suriname leest men den raad, dien men hun gaf: een Europeesch landbouwer kan hier niet bestaan, maar voor flinke ambachtslieden is er best een stuk brood te verdienen. Het is zoo uitgekomen. De derde 
groep van zendelingen, die naar Suriname uitgezonden werd, telde ambachtslieden en een flinken dokter.

Kleermakerij en bakkerij werden geopend; deze laatste kreeg al heel spoedig de levering van 1100 broodjes voor het gouvernement; een bewijs, dat de zaak goed was aangepakt.

De schoenmakerij in Berbice was geruimen tijd de kurk, waarop de huishouding der zending dreef.

Er waren niet veel ambachten, die de broeders niet uitoefenden. In het Diarium van Hoop leest men, dat met Kerstmis aan de kinderen kaarsen van Surinaamschen was waren uitgedeeld. Hoop was de laatste zendingspost, en het vermoeden ligt voor de hand, dat de kaarsen ook zelf gegoten waren, zooals men ook zelf de booten bouwde, waarmee men over zee naar Paramaribo ging.

Uit deze school zal zeer stellig de ambachtsman van Suriname zijn voortgekomen. De namen van baas Maasdamme, Duysker en anderen onder hen hebben nu nog een goeden klank. Grootendeels behooren de ambachtslieden, die zich allengs hebben opgewerkt, nu nog tot de gemeente.

Sterker dan de uiterlijke beïnvloeding is de geestelijke inwerking geweest, die niet in cijfers kan worden vastgelegd, maar toch ook wel zich openbaart in uiterlijke dingen, bijv. in den eeredienst.

In de eerste plaats zou ik het Herrnhutter geestelijk lied willen noemen. Herrnhut was een zingende gemeente met een groote schat van kerkelijke liederen, die men kende en zong. Reeds uit de eerste berichten blijkt, welken invloed het gezongen lied op de hoorders had. Al verstond men de woorden niet, toch verdrong het volk zich onder de ramen, zoo zelfs dat de overheid genoopt was in te grijpen.

Spoedig nam men de wijzen met de onbekende woorden over; het eerste vertaalde werk was bij Creool en Indiaan de kerkzang.

Van welke beteekenis het lied was, blijkt uit de verhalen van de Boschnegers, die Saron aan de Saramacca hadden overvallen en vrouwen en kinderen meegenomen. $\mathrm{Zij}$ verboden $\mathrm{nl}$. bij hun aftocht aan de vrouwen uitdrukkelijk haar liederen te zingen, omdat zij bang waren voor deze gezangen, die zij waarschijnlijk niet eens verstonden. Men kan gerust zeggen, dat het Herrnhutterlied het lied van de kolonie is geworden, dat nu door alle gezindten bij alle gelegenheden gezongen wordt. Hiertoe heeft natuurlijk ook meegewerkt het onderwijs op de Herrnhutterscholen, waar de zang altijd een zeer geliefd vak was. 
Het Herrnhutterlied heeft het Afrikaansche lied vrijwel geheel verdrongen, en pas in den laatsten tijd zijn de zangen van het Leger des Heils in gebruik gekomen. Nog zingt de schipper van een Coronie kotter den geheelen nacht door lied na lied, en een serenade van verscheidene uren koraalzang is geen zeldzaamheid.

Het onderwijs in Suriname is afkomstig van de Broedergemeente. Hoe leiding gevend de Broedergemeente op dit gebied was, blijkt wel hieruit, dat wijlen dr. Benjamins, de eerste inspecteur van het onderwijs, zich tot den hoofdonderwijzer van de Broedergemeente en tot zendeling Renckewitz wendde om een leerplan voor de openbare school.

De „Centraalschool” van de Evangelische Broedergemeente is de plaats, vanwaaruit zich de invloed van het onderwijs naar alle richtingen heeft uitgestrekt. De Kerstfeestviering op school heeft daar haar oorsprong gehad.

Het zou te ver voeren den invloed van de Broedergemeente op het schoolwezen verder uit te werken. Ik verwijs naar het pas verschenen vlugschrift Groei van den heer E. A. v. Themen.

Laten wij thans ons tot den eeredienst bepalen.

Daar heeft de viering van den lijdenstijd wel den diepsten indruk gemaakt.

In den "stillen tijd”, de laatste zeven weken voor Paschen, mocht er in de gemeente in geen geval gedanst worden. Ook mochten er geen luidruchtige feesten plaats vinden. De dracht was wit (witte kleeren spelen in de Broedergemeente een belangrijke rol als symbool van de gemeente der Zaligen, die door het „Blut des Lammes" zijn rein gewasschen van alle zonden). Niet alleen de gemeente heeft zich aan dezen regel gehouden; ook de vreemdeling, zelfs de heiden, deed dit. Het is voor een vreemde een aangrijpend gezicht om op den Goeden Vrijdag ook nu nog een talrijke gemeente in smetteloos witte kleeren den dienst in een volle kerk te zien bijwonen. Vroeger lieten de kerkdienaren niemand toe, die niet in het wit gekleed was, en de gewoonte om in het wit te gaan is zeer diep ingeworteld.

Zulk een diepen indruk heeft de viering van den lijdenstijd gemaakt met haar zangdiensten en talrijke lijdensliederen, dat ook nu nog de bioscopen zich gedwongen zien voor dien tijd eenige godsdienstige films in voorraad te hebben; zelfs wordt er dan bij advertentie bekend gemaakt, dat het zingen van kerkelijke liederen onder de vertooning geoorloofd is. 
Ook de Kerstfeestviering is diep ingeworteld. Vooral het uitdeelen van brandende kaarsen onder den kerkdienst, een oud gebruik, is indrukwekkend. Bij het geschenk, waarop iedere dienstbode met Kerstmis rekent, behoort een kaars, liefst een waskaars, in ieder geval lang en dik.

De Kerstboom is meer Duitsch dan bepaald Herrnhuttersch. Meer in de kerken en scholen dan in de huizen heeft deze zijn intree gedaan. Hierbij zullen de kosten hun invloed hebben doen gelden. Maar Kerstfeest behoort men ook in de kerk te vieren; elke begi of kerkelijke vereeniging heeft zulk een kerkelijke kerstfeestviering.

Bij Kerstmis behoort het kerkwasschen, dat tegen Pinksteren herhaald wordt. Het is de groote schoonmaak in de huizen, die tegen die jaargetijden wordt gehouden.

De luidruchtige viering der jaarwisseling heeft de Broedergemeente niet kunnen tegengaan. Wel wordt de dienst om half twaalf 's nachts druk bezocht, maar in sommige kerken heeft men deze moeten laten vervallen om het oorverdoovende lawaai en vuurwerk tot vlak voor de kerkdeur.

Ook op de begrafenissen kan nog gewezen worden. Overweldigend was de toeloop, toen zendeling Gartmann als eersteling op de eerste eigen begraafplaats der broeders volgens Herrnhuttergebruik werd begraven. En vele jaren lang heeft de gemeente gestreden tegen bijgeloof en afgodische dingen, die juist bij sterfgevallen het hoofd weer opstaken. Men heeft de kerkdienaren den geheelen nacht bij het lijk laten waken, en een gilde van lijkbewasschers en dragers gevormd, om alle wangebruiken, waarvan men soms de afkomst en beteekenis niet kende, tegen te gaan.

$\mathrm{Nu}$ kan men gerust zeggen, dat de begrafenis met haar litanie en het inzegenen van den doode sterk Herrnhuttersch gekleurd is, ook in de andere gemeenten.

Nog op éen ding zou ik willen wijzen, nl. op de begi's of gebedsvereenigingen. Deze zijn vereenigingen op godsdienstigen grondslag, ten doel hebbende de versterking van het geloofsleven, en daarnaast sociaal werk. In deze begi's met haar kleine wekelijksche bijdragen heeft men aan de bevolking de waarde van de cent geleerd. Hier werd bewezen, dat de kleinste wekelijksche bijdrage ten slotte tot een kapitaaltje wordt, dat voor de arme bevolking tevoren altijd een onbereikbaar ideaal was geweest. Door haar 
populariteit zijn de begi's, die de macht van de samenwerking en van het kleine bewezen, een groote steun voor de gemeenten geweest en zij zijn het nog.

Ook de geest van broederliefde komt in de begi's tot zijn recht. De leden helpen elkaar bij ziektegevallen; zij waken bij den zieke en geven den overledene een trouw uitgeleide. Voorbeelden van echt christelijke naastenliefde en van gemeente-patriotisme geven zij te zien.

Het zou, zooals in het begin gezegd is, zeker de moeite loonen dit onderwerp grondiger te behandelen. Ik heb alleen getracht, enkele in het oog springende punten aan te wijzen, om daarmee aan te toonen, dat de invloed van de zending op het volk zeer groot is. Het zal waarschijnlijk zoo zijn, dat men zich het Surinaamsche volk niet meer kan voorstellen zonder de Herrnhutterzending.

Paramaribo, 4 Augustus 1935. 